Original Research Paper

\title{
Identifying Factors Influencing Production and Rice Farming Income with Approach of Path Analysis
}

\author{
Max Nur Alam and Effendy \\ Department of Agriculture Economics, Faculty of Agriculture, \\ Tadulako University, Palu Indonesia 94116, Indonesia
}

Article history

Received: 08-02-2017

Revised: $15-03-2017$

Accepted: 21-03-2017

Corresponding Author:

Max Nur Alam

Department of Agriculture

Economics, Faculty of

Agriculture, Tadulako

University, Palu Indonesia

94116, Indonesia

Email: nuralam_max@yahoo.co.id

\begin{abstract}
This research analyzes direct and indirect factors that potentially affected rice quality, rice price at the farmers' level, rice production and farming income. The target population in this research were farmers who farmed on rice land area ranging from 0.5 to 2.0 ha. A multistage, stratified cluster sampling was used in this research. This research employed a survey of 300 household heads, chosen randomly. Results showed that NPK fertilizers (Nitrogen, Phosphorus, Potassium), organic fertilizers and labor had a direct effect on rice production. Rice quality had a direct effect on its price at the farmers' level, while organic fertilizers and labor directly affected rice quality. Labor had a negative correlation to rice quality, showing that technologies were very much needed to improve. Rice price at the farmers' level and production had a direct effect on the income of rice farming, while the organic fertilizers had an indirect effect. These results have the potential to help the government and agricultural professionals design effective agricultural interventions to increase rice quality, price at the farmers' level and production so that farming income could increase.
\end{abstract}

Keywords: Quality, Price, Production, Income, Rice Farming

\section{Introduction}

Rice production needs to increase to fulfill the food needs of the growing population. More than half of world's population uses rice as a staple food, including all of Indonesian society (Cantral and Reeves, 2002; Davidson et al., 1979). Rice needs in Indonesia have risen to more than 30 million tons per year. The rate of population growth and the level of rice consumption are still relatively high, demanding continuous production enhancement efforts from the state. One way is through productivity enhancement.

Central Sulawesi is one of the rice-producing area in Indonesia, but the area has shown a trend of decreased productivity (SCSP, 2015). This decrease was due to a weather change, increased pest attack and disease. The low productivity of farming, according to Nwaru et al. (2006), will cause low income that results in the weak financial position of farmers whereby they cannot support their own economic activities. Technology improvements are essential for helping farmers increase their productivity and income. These provide opportunities for farmers to produce more food with fewer sacrifices (Adnyana and Kariyasa, 2006). The right policy for technology development, absorption and dissemination will grow rice production significantly (Sekar, 2014). Rice productivity is highly correlated with production factors including seeds, fertilizers, pesticides and labor (Effendy, 2010; Li et al., 2008). Rice farming has faced challenges with stagnated overall production at a low level of 2000-5000 kg/ha (Fan et al., 2012; Mueller et al., 2012; Laborte et al., 2012; Ray et al., 2012; Grassini et al., 2013; Chen et al., 2014).

Sustainability of rice farming is tied to income from farming. Income is determined by the amount of production and the cost of production. Generally farmers in Central Sulawesi Province sell rice after milling. The selling price of rice at the farmers' level was IDR $6500-7800 / \mathrm{kg}$.

Nurbaeti el al. (2006; Adnyana and Kariyasa, 2006; Mahananto et al., 2009; Malian et al., 2004) have all conducted research regarding Indonesia's various rice farming areas. Laborte et al. (2015; Rana et al., 2007) and others have done research concerning rice farming outside of Indonesia. In our research we analyze the correlation between production factors, rice quality, rice price, production and farming income. Path analysis was done to explore some direct and indirect factors that could potentially affect rice quality, price at the farmers' level, production and farming income. 


\section{Materials and Methods}

This research was conducted in Central Sulawesi Province, Indonesia. The target population in this research were farmers who farmed a rice land area 0.5 to 2.0 ha. A multistage, stratified cluster sampling was used in this research. First, five regencies were chosen randomly from a sample of twelve rice-producing regencies in Central Sulawesi province. Second, two rice-producing sub-regencies were chosen randomly of each regency. Third, two rice-producing villages were chosen randomly of each sub-regency. Fourth, fifteen household heads of each village were chosen randomly. Finally, 300 household heads were obtained into the research samples. Path analysis helped answer the research objectives. Path Model analysis that would be tested in this research is shown on Fig. 1.

Path model was used to test the direct and indirect relationships between variables. Exogenous variable were seeds, NPK fertilizers, organic fertilizers and labors. Endogenous variable were rice quality, rice price at the farmers' level, Rice production and Rice farming income. Goodness of fit of the final model was assessed with chi-square test and the goodness of fit indices, like Goodness-of-Fit Index (GFI), Adjusted Goodness-Of-Fit Index (AGFI), Normed Fit Index (NFI), Relative Fit Index (RFI), Incremental Fit Index (IFI), Comparative Fit Index (CFI) and Root Mean Square Error Of Approximation (RMSEA). Values for GFI, AGFI, NFI, RFI, IFI, TLI and CFI range from 0 to 1 with recommending values greater than 0.90 indicating a good fit and there is a good fit if RMSEA is less than 0.08 (Wang and Wang, 2012). Path model was analysed using LISREL 8.70 .

\section{Results and Discussion}

\section{Characteristics of Farmers}

About 300 household heads aged 24 to 62 years (average $=44.14$, standard deviation $(\mathrm{sd})=10.23$ ) were included in the sample. Table 1 presents the characteristics of respondents.

Table 1 shows that all the respondent farmers belong to the productive age (15 to 64 years) of farmers. More than half of the respondent farmers were still in elementary school. A quarter of respondent farmers held a farmable land area of less than 1 ha. Three-quarters of the respondent farmers had 1 to 2 ha to farm.

\section{Path Analysis}

Model estimation used the LISREL program with the default model as the maximum likelihood. Figure 2 and Table 2 shows model estimation. The final model had a good fit with chi-square $=16.52(\mathrm{df}=11, \mathrm{P}=0.12), \mathrm{GFI}$ $=0.96, \mathrm{AGFI}=0.88, \mathrm{NFI}=0.98, \mathrm{RFI}=0.95, \mathrm{IFI}=0.99$, $\mathrm{CFI}=0.99$ and RMSEA $=0.07$.

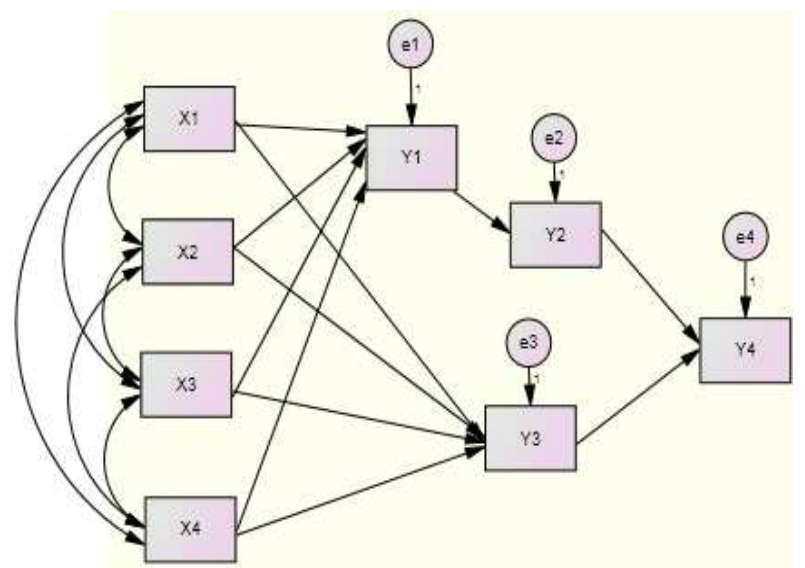

Fig. 1. Path analysis model

Where:

$\mathrm{X} 1=$ Seeds $(\mathrm{kg})$

$\mathrm{X} 2=$ NPK fertilizers $(\mathrm{kg})$

$\mathrm{X} 3=$ Organic fertilizers $(\mathrm{kg})$

$\mathrm{X} 4=$ Labors (day people working $=\mathrm{DPW})$

$\mathrm{Y} 1=$ Rice quality $(\%)$

$\mathrm{Y} 2=$ Rice price at the farmers' level (IDR)

$\mathrm{Y} 3=$ Rice production $(\mathrm{kg})$

$\mathrm{Y} 4=$ Rice farming income (IDR)

Figure 2 shows the correlation between associated factors with rice farming income. Each arrows presents standardized regression coefficients. Using the path analysis, we found that rice price and production at the farmers' level had a direct effect on rice farming income. Rice quality affected rice farming income indirectly, mediated by the enhancement in rice price at the farmers' level. Rice quality related positively to organic fertilizers and related negatively with labor. NPK fertilizers, organic fertilizers and labor had an indirect effect on rice farming income mediated by enhancement in rice production.

Direct effects, indirect effects and total effects of variables on rice farming income enhancement are presented in Table 3. Total effects were the sum of direct effects and indirect effects. Indirect effects represented the effects of one variable on another through direct effects. Among the total effects, rice price at the farmers' level was the greatest $(0.71)$, followed by the quality of rice (0.69), production $(0.59)$ and organic fertilizers $(0.46)$.

\section{Direct Effects}

Results of the path model revealed that NPK fertilizers, organic fertilizers and labor directly affected production. Yadav et al. (2013) found that nitrogen originating from organic and biological fertilizers being applied to rice-potato-onion cropping systems produced the best results. Ndruru et al. (2014; Effendy, 2010) also concluded that fertilizers had a positive effect on rice production. Rice quality had direct effects on rice price at 
the farmers' level-something also relevant to the cocoa price. One of the factors that determined cocoa price was the quality of cocoa beans (Effendy and Antara, 2015). Organic fertilizers had a direct effect on rice quality, which is consistent with Effendy and Antara (2015)'s research on cocoa farming, where fertilizers positively affected quality of cocoa beans. Labor had a negative correlation with rice quality, so that increasing rice quality required new technologies such as combine harvesters. These could cut, gather and thresh all at once, but most farmers do not have the capital elasticity needed for investment in such technologies. According to Ashari
(2009), this is a problem common across agricultural business the world over. To solve the problem, the government launched several capital programs involving loans or aid for farmers and agricultural business. This included revolving funds, capital gains, interest subsidies, as well as leading commercial. According to Nwaru et al. (2006), availability of credit is an important factor in production activity. Importance of credit based on the fact that the credit could increase the size of farming operations and resource productivity. In addition, it facilitates innovation adoption that increases production and farming income.

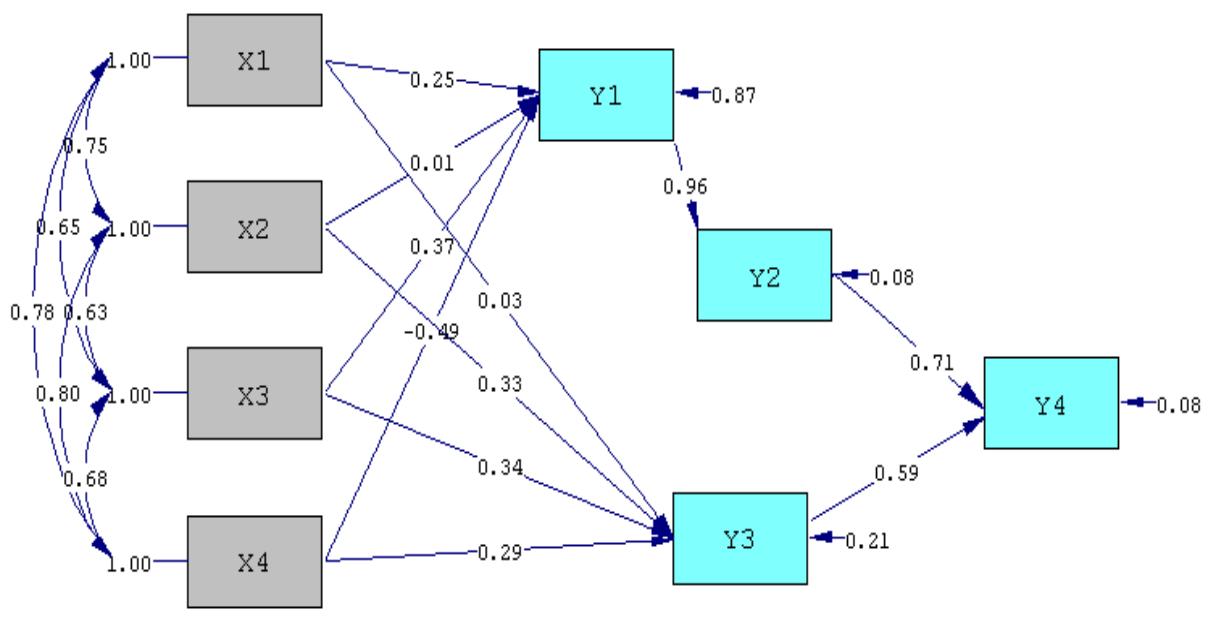

Chi-Square $=16.52, \mathrm{df}=11, \mathrm{P}$-value $=0.12302, \mathrm{RMSEA}=0.070$

Fig. 2. Final path model

Table 1. Characteristics of respondents

\begin{tabular}{llrr}
\hline Variables & Category or range & $\mathrm{n}$ & Percent \\
\hline Age (year) & Productive & 300 & 100.00 \\
Student classification & Elementary school & 159 & 53.00 \\
& High school students & 116 & 38.67 \\
& University students & 25 & 8.33 \\
Land area & $<1$ ha & 75 & 25.00 \\
& 1 to 2 ha & 225 & 75.00 \\
\hline
\end{tabular}

$\mathrm{n}=$ total respondent

Table 2. Path coefficients

\begin{tabular}{lllll}
\hline & & & Standardized \\
coefficient estimate & $\mathrm{R}^{2}$ \\
\hline Rice quality & Seed & $\mathrm{SE}$ & 0.25 & 0.13 \\
& NPK fertilizer & 0.16 & 0.01 & \\
& Organic fertilizer & 0.16 & $0.37^{* *}$ & \\
Rice price at the farmers' level & 0.13 & $-0.49^{* *}$ & 0.92 \\
Rice production & Labor & 0.18 & $0.96^{* *}$ & 0.79 \\
& Rice quality & 0.03 & 0.03 & $0.33^{* *}$ \\
Rice farming income & Seed & 0.08 & $0.34^{* *}$ & $0.29^{* *}$ \\
& NPK fertilizer & 0.08 & $0.71^{* *}$ & 0.92 \\
\hline
\end{tabular}

$* * \mathrm{p}<0.05$ 
Table 3. Standardized effects on rice farm by path analysis

\begin{tabular}{llll}
\hline Variables & Direct effects & Indirect effects & Total effects \\
\hline Seed & & 0.19 & 0.19 \\
NPK fertilizer & & 0.21 & 0.21 \\
Organic fertilizer & & $0.46^{* *}$ & $0.46^{* *}$ \\
Labor & & -0.17 & -0.17 \\
Rice quality & $0.71^{* *}$ & $0.69^{* *}$ & $0.69^{* *}$ \\
Rice price at the farmers' level & & $0.71^{* *}$ \\
Rice production & $0.59^{* *}$ & & $0.59^{* *}$ \\
\hline
\end{tabular}

$* * \mathrm{p}<0.05$

\section{Indirect Effects}

The Path Model showed that organic fertilizers and rice quality had positive indirect effects on rice farming income through their effects on the rice price at the farmers' level and rice production. Consistent with this research, one of the cocoa farming studies showed that increasing the usage of fertilizers and improvement of sanitation amounted to $25 \%$ had positive impacts on the enhancement of cocoa farming income amounting to $26.15 \%$ (Effendy, 2015). Rice quality determined the rice price at the farmers' level given by the milling section. Broken rice would be given a lower price, while intact rice would be given a higher price.

\section{Conclusion}

This research found that NPK fertilizers, organic fertilizers and labor had direct effects on rice production. Rice quality had a direct effect on the rice price at the farmers' level, while organic fertilizers and labor had a direct effect on rice quality. Labor correlated negatively to rice quality, demonstrating a need for technological improvement. The rice price at the farmers' level and production had direct effects on rice farming income, while organic fertilizers had indirect effects. These results could help governments and agricultural professionals to design effective agricultural interventions that increase rice quality, price at farmers' level and production so as to increase farming income and thereby make farming a more attractive pursuit. Income enhancement would contribute to the sustainability and growth of rice farming in the long term.

\section{Acknowledgement}

The authors liked to thank the reviewers so this paper could be published.

\section{Funding Information}

This article was funded by the Tadulako University. The funders had no role in study design, data collection and analysis, decision to publish, or preparation of the manuscript.

\section{Authors Contributions}

Max Nur Alam: Coordinated the study, Designed and wrote the manuscript.

Effendy: Analyzed data and helped in drafting the manuscript.

\section{Ethics}

This article is original and contains unpublished material.

\section{References}

Adnyana, M.O. and Kariyasa, 2006. Impact and perception of farmers against implementation system of rice integrated crop management. J. Penelitian Pertanian Tanaman Pangan, 25: 21-29.

Ashari, 2009. Policy optimazation of credit program for agricultural sector in Indonesia. Anal. Kebijakan Pertanian, 7: 21-42.

Cantral, R.P. and T.G. Reeves, 2002. The cereal of the world's poor takes center stage. Science, 296: 53-53. DOI: 10.1126/science.1070721

Chen, X.P., Z.L. Cui, M.S. Fan, P. Vitousek and M. Zhao et al., 2014. Producing more grain with lower environmental costs. Nature, 514: 486-489. PMID: 25186728

Davidson, S., R. Passmore, J.F. Brook and A.S. Truswell, 1979. Human Nutrition and Dietetics. 7th Ed., Livingstone, Churchill, New York.

Effendy and M. Antara, 2015. Effect of input production against quality of cocoa beans. Am. J. Applied Sci., 12: 709-713. DOI: 10.3844/ajassp.2015.709.713

Effendy, 2010. Production factor efficiency and income of wetland rice farm in Masani village poso pesisir sub district poso regency. J. Agroland, 17: 233-240.

Effendy, 2015. Increasing of cocoa farmers household income with two stage least squares method. Modern Applied Sci., 9: 120-127.

Fan, M.S., J.B. Shen, L.X. Yuan, R.F. Jiang and X.P. Chen et al., 2012. Improving crop productivity and resource use efficiency to ensure food security and environmental quality in China. J. Exp. Botany, 63: 13-24. DOI: $10.1093 / \mathrm{jxb} / \mathrm{err} 248$ 
Grassini, P., K.M. Eskridge and K.G. Cassman, 2013. Distinguishing between yield advances and yield plateaus in historical crop production trends. Nature Commun., 4: 2918-2918.

DOI: $10.1038 /$ ncomms3918

Laborte, A.G., K. De Bie, E.M.A. Smaling, P.F. Moya and A.A. Boling et al., 2012. Rice yields and yield gaps in Southeast Asia: Past trends and future outlook. Eur. J. Agronomy, 36: 9-20.

DOI: $10.1016 /$ j.eja.2011.08.005

Laborte, A.G, N.C. Paguirigan, P.F. Moya, A. Nelson and A.H. Sparks et al., 2015. Farmers' preference for rice traits: Insights from farm surveys in central Luzon, Philippines, 1966-2012. Plos One, 10: 1-18. DOI: 10.1371/journal.pone.0136562

Li, X., Y. Luo, Q. Gao, S. Dong and X. Yang, 2008. Farm production growth in the upper and middle parts of the yellow river basin, China, during 1980-1999. Agric. Sci. China, 7: 344-355. DOI: $10.1016 / \mathrm{S} 1671-2927(08) 60075-9$

Mahananto, S., Sutrisno and C.F. Ananda, 2009. Analysis of influencing factors in increasing rice production (case study in the nogosari-subdistrict, boyolali regency, central java province). J. Wacana, 12: 179-191.

Malian, A.H., S. Mardianto and M. Ariani, 2004. Factors that affect production, consumption and rice price as well as inflation of food. J. Agro Ekonomi, 22: 119-146. DOI: 10.21082/jae.v22n2.2004.119-146

Mueller, N.D., J.S. Gerber, M. Johnston, D.K. Ray and N. Ramankutty et al., 2012. Closing yield gaps through nutrient and water management. Nature, 490: 254-257. DOI: 10.1038/nature 11420

Ndruru, R.E., M. Situmorang and G. Tarigan, 2014. Analysis of factors that affect results of rice production in deli serdang. Saintia Matematika, 2: 71-83.
Nurbaeti, B., S.L. Mulijanti and T. Fahmi, 2006. The implementation of Integrated Crop and resource Management (ICM) on paddy in sumedang district. J. Pengkajian dan Pengembangan Teknol. Pertanian, 11: 268-279.

Nwaru, J.C., C.E. Onyenweaku and A.C. Nwosu, 2006. Relative technical efficiency of credit and non-credit user crop farmers. African Crop Sci. J., 14: 241-251.

Rana, R.B., C. Garforth, B. Sthapit and D. Jarvis, 2007. Influence of socio-economic and cultural factors in rice varietal diversity management on-farm in Nepal. Agric. Hum. Values, 24: 461-472. DOI: $10.1007 / \mathrm{s} 10460-007-9082-0$

Ray, D.K., N. Ramankutty, N.D. Mueller, P.C. West and J.A. Foley, 2012. Recent patterns of crop yield growth and stagnation. Nature Commun., 3: 1293. DOI: $10.1038 /$ ncomms 2296

Sekar, I., 2014. Supply of rice (Oryza sativa) commodity in India: Insights on domestic production performance. Ind. J. Agric. Sci., 84: 907-913.

SCSP, 2015. Central sulawesi in figures. SCSP-Statistics of Central Sulawesi Province Office, Statistics of Central Sulawesi Province.

Wang, J. and X. Wang, 2012. Structural Equation Modeling: Applications using Mplus. 1st Edn., Thomson Digital, Noida, pp: 453.

Yadav, S.K., Y. Singh, M.K. Yadav, S. Babu and K. Singh, 2013. Effect of organic nitrogen sources on yield, nutrient uptake and soil health under rice (Oryza sativa) based cropping sequence. Ind. J. Agric. Sci., 83: 170-175. 